\title{
Pengaruh sanitasi terhadap tingkat kepuasan pasien dirumah sakit daerah Kabupaten Kuantan Singingi
}

\author{
Putri Permatasari ${ }^{1}$, Ridwan Manda Putra ${ }^{2}$ Agrina $^{3}$ \\ ${ }^{1}$ Mahasiswa Magister Ilmu Lingkungan Pascasarjana Universitas Riau \\ ${ }^{2}$ Dosen Magister Ilmu Lingkungan Pascasarjana Universitas Riau \\ ${ }^{3}$ Dosen Fakultas Keperawatan Universitas Riau \\ *Correspondent email : ayie28.pps@gmail.com
}

Diterima: 17 Februari 2021 | Disetujui: 28 Februari 2021 | Diterbitkan: 28 Februari 2021

\begin{abstract}
In hospital health care facilities, sanitation problems are the most important thing, the existence of problems such as clean water, sewage systems, conditions of garbage bins, sewerage systems and sanitation of building spaces cause discomfort for patients being treated. The inpatient room is part of the inpatient installation and is the most important part of the hospital. Therefore, this study aims to determine the effect of sanitation on the satisfaction level of inpatients at the General Hospital of Kuantan Singingi Regency. This research is a quantitative study using the spearmank rank analysis method. The research subjects were patients or their families who were waiting for the patient in the ward. The sample in this study amounted to 70 respondents, with the sampling technique incidental sampling. The analysis was carried out by using the Chi-Square test, the results showed that there was an influence between clean water sources, the $P$ value $=16,556$, the sewage system $(X 2)$, the $P$ value $=$ 16,170 , the trash bin condition $(X 3)$, the $P$ value $=16,640$ variables. condition of sewerage $(X 4)$ obtained $P$ value $=12,685$ and sanitation of building space $(X 5)$ obtained $P$ value $=17,637$ level of patient satisfaction at the General Hospital of Kuantan Singingi Regency. The results concluded that there is an influence between all independent variables (sanitation) and the dependent variable (satisfaction). Based on the results of research on inpatient respondents at the Kuantan Singingi Hospital, namely the patient was satisfied and comfortable with the services provided. The satisfaction of these patients can improve the image and quality of the Kuantan Singingi Hospital to be good among the public and the government in Kuantan Singingi Regency.

Keywords: sanitation; clean water; disposal system; trash can conditions; wastewater disposal and sanitation of building spaces
\end{abstract}

Sanitasi adalah suatu upaya yang dilakukan oleh manusia untuk mewujudkan dan menjamin kondisi lingkungan (terutama lingkungan fisik yaitu tanah, air, dan udara) yang memenuhi syarat-syarat kesehatan. Sanitasi rumah sakit merupakan bagian dari kesehatan lingkungan rumah sakit (Sabarguna, 2011). Kesehatan lingkungan rumah sakit diartikan sebagai upaya penyehatan dan pengawasan lingkungan rumah sakit yang mungkin berisiko menimbulkan penyakit dan atau gangguan kesehatan bagi masyarakat sehingga terciptanya derajat kesehatan masyarakat yang setinggi-tingginya. Pelayanan rawat inap adalah pelayanan kesehatan perorangan yang meliputi observasi, diagnosa, pengobatan, keperawatan, rehabilitasi medik dengan menginap di ruang rawat inap, oleh karena penyakitnya penderita harus menginap.

Sanitasi Rumah Sakit adalah upaya pengawasan berbagai faktor lingkungan fisik, kimiawi dan biologis dirumah sakit yang menimbulkan atau mungkin dapat mengakibatkan pengaruh buruk terhadap kesehatan petugas, penderita, pengunjung maupun bagi masyarakat disekitar rumah sakit.

Sanitasi Rumah Sakit harus diperhatikan karena merupakan upaya yang tidak dapat dipisahkan dari sistem pelayanan kesehatan didalam rumah sakit itu sendiri dalam memberikan layanan kepada pasien sebaik-baiknya. Karena tujuan sanitasi rumah sakit adalah menciptakan kondisi lingkungan yang bersih, nyaman dan dapat mencegah terjadi infeksi silang serta mencemari lingkungan.

Kemajuan dan perkembangan rumah sakit akan sangat bergantung dari kualitas pelayanan yang diberikan. Jika pelayanan yang diberikan baik maka pasien di rumah sakit akan merasa puas. Oleh karena itu peran petugas rumah sakit seperti dokter, perawat ataupun staf lain di rumah sakit sangat penting. Berkualitas atau tidak rumah sakit tersebut dalam melakukan pelayanan kesehatan kepada pasien, dapat 


\section{SEHATI}

Jurnal Kesehatan

Vol 1, No 1, Februari 2021, p. 22-32

e-ISSN : 2775-6963 | p-ISSN : 2775-6955

diukur dari tingkat kepuasaan pasien, jumlah kunjungan pasien, penggunaan peralatan modern, frekuensi keluhan terhadap pelayanan dan pendapatan rumah sakit (Kotler, 2000). Pada umumnya pasien yang merasa tidak puas akan mengajukan komplain pada pihak rumah sakit. Komplain yang tidak segera ditangani akan mengakibatkan menurunnya kepuasan pasien terhadap kapabilitas pelayanan kesehatan di rumah sakit tersebut.

Rumah Sakit Umum Daerah (RSUD) sebagai institusi pelayanan kesehatan tipe C yang dimiliki oleh pemerintah daerah, diharapkan dapat memberikan pelayanan yang sesuai dengan harapan dan kebutuhan pelanggan (masyarakat). RSUD mempunyai fungsi memberikan pelayanan kesehatan tentunya harus sesuai dengan standar yang telah ditentukan (Nawangsari, 2011). Rumah sakit terdiri dari beberapa bagian yaitu instalasi rawat jalan berupa UGD dan poli, instalasi rawat inap serta sarana penunjang medis seperti apotik dan laboratorium. Ruang rawat inap merupakan bagian dari instalasi rawat inap dan merupakan bagian yang terpenting di rumah sakit merupakan tempat pasien dirawat serta adanya para pengunjung pasien. Berdasarkan hasil survei awal didapatkan beberapa permasalahan terkait sanitasi yang tampak di RSUD Kabupaten Kuantan Singingi yaitu untuk kamar mandi dan wc khususnya di ruangan rawat inap kelas tiga berada diluar ruangan, digunakan secara bersama-sama oleh pasien dan pengunjung terdapat adanya genangan air serta berbau busuk. Tempat pembuangan sampah ada yang tidak memiliki tutup dan adanya sampah berserakan disekitar lingkungan rawat inap. Pembuangan air limbah, sebagian besar ruangan yang menghasilkan limbah dibuang kesaluran induk Instalasi Pengelolaan Air Limbah (IPAL) tetapi ada beberapa ruangan seperti ruangan laboratorium pemeriksaan patologi dan ruangan laundry terlebih dahulu melalui tangki pre treatment basin (PTB), kemudian baru ke saluran induk IPAL. Limbah yang berasal dari instalasi gizi atau dapur terlebih dahulu melalui tahap pemisahan lemak pada bak penangkap lemak, sehingga air yang terpisah dari lemak dan sisa-sisa makanan akan mengalir ke tangki PTB yang kemudian akan mengalir ke induk IPAL.

Upaya tata laksana udara di RSUD Kabupaten Kuantan Singingi untuk mengatur penghawaan dan pengaturan udara di rumah sakit sudah dilakukan yaitu menggunakan sistem pendingin yang dipelihara dan dioperasikan dengan baik. Selain itu suplai udara koridor atau buangan exhaust fan dari tiap ruang tidak digunakan sebagai suplai udara kecuali untuk suplai udara ke WC, toilet dan gudang.

Rumah Sakit Umum Daerah Kabupaten Kuantan Singingi selalu meningkatkan kualitas pelayanan guna mencapai target yang diharapkan. Sanitasi rumah sakit sangat penting, terutama di tempat-tempat umum yang erat kaitannya dengan pelayanan untuk orang banyak. Lingkungan yang sanitasinya buruk dapat menjadi sumber berbagai penyakit yang dapat mengganggu kesehatan manusia. Adanya upaya sanitasi diharapkan dapat dikurangi pengaruh buruk seperti timbulnya pencemaran bakteri dan bahan berbahaya pada lingkungan rumah sakit, yang menjadi penularan penyakit dan kejadian infeksi.

Rumah sakit merupakan tempat yang memudahkan penularan berbagai penyakit infeksi, untuk itu upaya sanitasi sangat diperlukan. Penelitian tentang sanitasi yang dilakukan oleh Febri, dkk (2018) mengemukakan bahwa kualitas pelayanan yang diberikan oleh Puskesmas Kuantan Singingi, dipandang kurang baik oleh masyarakat. Seperti Ruang tunggu yang masih kurang, kesediaan dokter, dan lain sebagainya. Selama ini pelayanan yang maksimal kepada masyarakat hanyalah sebatas slogan saja, pelayanan di Puskesmas masih belum bisa maksimal, seperti jumlah tenaga medis yang masih kurang, jumlah fasilitas yang belum lengkap, dan juga ruang tunggu yang ada tidak memadai untuk menampung pasien yang datang ke Puskesmas, sehingga memberikan citra bahwa puskesmas itu pelayanannya kurang baik, dan hanya untuk masyarakat kelas bawah. Sehingga masyarakat merasa enggan untuk berobat.

Berdasarkan penelitian sebelumnya ditemukan bahwa masalah sanitasi rumah sakit perlu mendapat perhatian dalam rangka pelayanan kesehatan masyarakat, maka penulis tertarik untuk melakukan penelitian sanitasi ruang rawat inap di Rumah Sakit Umum Daerah Kabupaten Kuantan Singingi.

\section{METODE PENELITIAN}

Menurut Keputusan Menteri Kesehatan Republik Indonesia Nomor 983/MenKes/SK/XI/1992, rumah sakit merupakan suatu unit yang mempunyai organisasi teratur, tempat pencegahan dan penyembuhan penyakit, peningkatan dan pemulihan kesehatan penderita yang dilakukan secara multidisiplin oleh berbagai kelompok profesional terdidik dan terlatih, yang menggunakan prasarana dan sarana fisik. Rumah sakit yang memberikan pelayanan kesehatan yang bersifat dasar, spesialistik, dan subspesialistik disebut rumah sakit umum. Tugas rumah sakit umum adalah melaksanakan upaya kesehatan secara berdaya guna dan berhasil guna dengan mengutamakan upaya penyembuhan dan pemeliharaan yang dilaksanakan secara serasi dan terpadu dengan upaya peningkatan dan pencegahan serta melaksanakan 
rujukan. Sedangkan menurut Undang-Undang No. 14 Tahun 2009 tentang Rumah Sakit, yang dimaksudkan dengan rumah sakit adalah institusi pelayanan rawat inap, rawat jalan dan rawat inap.

\section{Sanitasi Lingkungan Rumah Sakit}

Sanitasi adalah suatu upaya yang dilakukan oleh manusia untuk mewujudkan dan menjamin kondisi lingkungan (terutama lingkungan fisik yaitu tanah, air, dan udara) yang memenuhi syarat-syarat kesehatan. Sanitasi rumah sakit merupakan bagian dari kesehatan lingkungan rumah sakit (Sabarguna, 2011). Sanitasi lingkungan merupakan suatu kondisi untuk mencapai lingkungan sehat melalui pengendalian faktor lingkungan fisik, khususnya hal-hal yang memiliki dampak merusak perkembangan fisik kesehatan dan kelangsungan hidup manusia. Sanitasi lingkungan mempunyai kedudukan yang paling penting dalam kehidupan sehari-hari, karena berpengaruh terhadap kesehatan seseorang dan masyarakat. Sanitasi lingkungan dapat mencerminkan tata cara hidup dari masyarakat tersebut. Untuk mendapatkan kondisi sanitasi lingkungan yang baik sangat bergantung dari tata cara dan perilaku masyarakat di dalam memelihara kualitas sanitasi lingkungannya.

Penelitian tentang sanitasi rumah sakit telah dilakukan oleh (Febri, Furwanti \& Hendriani, 2018), kualitas pelayanan yang diberikan oleh Puskesmas Kuantan Singingi, dipandang kurang baik oleh masyarakat. Seperti Ruang tunggu yang masih kurang, ketersediaan dokter, dan lain sebagainya. Selama ini pelayanan yang maksimal kepada masyarakat hanyalah sebatas selogan saja, pelayanan di Puskesmas masih belum bisa maksimal, seperti jumlah tenaga medis yang masih kurang, jumlah fasilitas yang belum lengkap, dan juga ruang tunggu yang ada tidak memadai untuk menampung pasien yang datang ke Puskesmas, sehingga memberikan citra bahwa puskesmas itu pelayanannya kurang baik, dan hanya untuk masyarakat kelas bawah. Sehingga masyarakat merasa enggan untuk berobat ke Puskesmas.

Menurut penelitian Utami (2018) bahwa dampak yang ditimbulkan dari sanitasi lingkungan terhadap kesehatan masyarakat di lingkungan 04 Kelurahan Pasar Madang Kecamatan Kota Agung Kabupaten Tanggamus. Ada pengaruh antara kondisi jamban, kondisi saluran pembuangan air limbah, kondisi tempat pembuangan sampah, dan kondisi rumah sehat yang belum memenuhi syarat kesehatan, terhadap kesehatan masyarakat berupa timbulnya penyakit seperti diare, demam berdarah, TB paruparu.

Adapun sanitasi di lingkungan rumah sakit dapat dilihat dari beberapa aspek yaitu:

\section{Sistem Air Bersih}

Sistem air bersih harus direncanakan dan dipasang dengan mempertimbangkan sumber air bersih dan sistem distribusinya. Sumber air bersih dapat diperoleh dari sumber air berlangganan dan/atau sumber air lainnya yang memenuhi persyaratan kesehatan sesuai dengan peraturan perundang-undangan. Perencanaan sistem distribusi air bersih dalam bangunan ruang rawat inap harus memenuhi debit air dan tekanan minimal yang disyaratkan. Ketentuan lebih lanjut mengenai tata cara perencanaan, pemasangan, dan pemeliharaan, sistem air bersih pada bangunan Ruang rawat inap mengikuti SNI 03 - 6481 - 2000 atau edisi terakhir, Sistem Plambing 2000, atau pedoman dan standar teknis lain yang berlaku.

\section{Sistem Pembuangan Air Kotor Atau Air Limbah}

Air limbah atau air buangan adalah sisa air yang dibuang yang berasal dari rumah tangga, industri maupun tempat-tempat umum lainnya dan pada umumnya mengandung bahan-bahan atau zat-zat yang dapat membahayakan bagi kesehatan manusia serta mengganggu lingkungan hidup. Kondisi saluran pembuangan air limbah harus memenuhi syarat kesehatan yaitu tertutup, mengalir lancar, dan tidak menimbulkan bau. Sistem pembuangan air kotor dan/atau air limbah harus direncanakan dan dipasang dengan mempertimbangkan jenis dan tingkat bahayanya (Adisasmito, 2007).

\section{Sistem Pembuangan Kotoran dan Sampah}

Sampah adalah suatu bahan atau benda padat yang sudah tidak dipakai oleh manusia, atau benda padat yang sudah tidak digunakan lagi dalam suatu kegiatan manusia dan dibuang. Pengelolaan sampah adalah meliputi penyimpanan, pengumpulan dan pemusnahan sampah yang dilakukan sedemikian rupa sehingga sampah tidak mengganggu kesehatan masyarakat dan lingkungan hidup (Prakash, 2010). 


\section{Sanitasi Ruang Bangunan}

Sanitasi ruang bangunan dan peralatan non medis dimaksudkan untuk menciptakan sanitasi ruang bangunan dan peralatan non medis yang nyaman, bersih, dan sehat di lingkungan rumah sakit agar tidak menimbulkan dampak negatif terhadap pasien, pengunjung dan karyawan.

Hal ini sejalan dengan penelitian yang dilakukan menunjukan bahwa pada ruang rawat inap masih terdapat ketidaksesuaian antara hasil pengukuran suhu ruangan, kelembaban, pencahayaan dan kadar debu di Rumah Sakit dengan persyaratan Kepmenkes No. 1204/2004.

\section{Tingkat Kepuasan Pasien Rumah Sakit}

Kemampuan rumah sakit memenuhi kebutuhan pasien dapat diukur dari kepuasan pasien. Pelanggan umumnya mengharapkan produk berupa barang dan jasa yang dikonsumsi dapat di terima dan dinikmatinya dengan pelayanan yang baik dan

Kata kepuasan atau satisfaction berasal dari bahasa Latin "satis" (artinya cukup baik, memadai) dan "facto" (melakukan, membuat). Secara sederhana kepuasan dapat diartikan sebagai upaya pemenuhan sesuatu atau membuat susuatu memadai. Namun ditinjau dari perspektif perilaku konsumen, istilah kepuasan pelanggan lantas menjadi sesuatu yang kompleks (Tjiptono, 2005). Kepuasan pasien merupakan indikator penting dan sering digunakan untuk mengukur kualitas dalam pelayanan kesehatan. Kepuasan pasien mempengaruhi hasil klinis, retensi pasien, dan klaim malpraktik medis. Pasien sama seperti konsumen, sekarang ini pasien melihat dirinya sebagai pembeli pelayanan kesehatan. Setiap pasien memiliki hak-hak tertentu, utamanya menekankan pada pemberian perawatan kesehatan yang berkualitas (Prakash, 2010).

Penelitian tentang hubungan mutu pelayanan kesehatan dengan kepuasan pasien rawat inap di rumah Sakit Sultan Daeng Radja memperoleh hasil 28,8\% menyatakan puas dengan kenyamanan yang diperoleh, $58,1 \%$ menyatakan tidak puas. Untuk pelayanan informasi $61,2 \%$ menyatakan puas, $83,6 \%$ menyatakan tidak puas terhadap informasi yang diberikan Dari segi akses atau keterjangkauan terdapat $71,6 \%$ menyatakan terjangkau dan $54,1 \%$ menyatakan akses tidak terjangkau. Pada kompetensi teknis, $78,9 \%$ menyatakan tidak puas, $82,1 \%$ menyatakan puas dengan pelayanan petugas (Wati, 2012).

Jenis penelitian ini adalah kuantitatif dianalisis dengan menggunakan analisis Korelasi Spearman Rank. Penelitian ini dilakukan di Rumah Sakit Umum Daerah Kabupaten Kuantan Singingi pada bulan Desember 2019 dengan jumlah sampel 70 orang.

\section{Analisa Data}

Analisis data mengacu pada ketiga tujuan yaitu

1. Menganalisis sanitasi (air bersih, sistem pembuangan air limbah, sistem pembuangan kotoran/jamban, sistem pembuangan sampah, dan sanitasi ruang bangunan di ruang rawat inap Rumah Sakit Umum Daerah Kabupaten Kuantan Singingi

Analisis sanitasi (air bersih, sistem pembuangan air limbah, sistem pembuangan kotoran/jamban, sistem pembuangan sampah dan sanitasi ruang bangunan) dianalisis secara deskriptif. Menggambarkan secara keseluruhan sanitasi (air bersih, sistem pembuangan air limbah, sistem pembuangan kotoran/jamban, sistem pembuangan sampah, dan sanitasi ruang bangunan di ruang rawat inap Rumah Sakit Umum Daerah Kabupaten Kuantan Singingi. Menggunakan statistik Non Parametrik yaitu Chi Square, data yang berbentuk kualitatif dijadikan data kuantitatif.

2. Menganalisis pengaruh sanitasi terhadap kepuasan pasien (air bersih, sistem pembuangan air limbah, sistem pembuangan kotoran/jamban, sistem pembuangan sampah, dan sanitasi ruang bangunan) di ruang rawat inap Rumah Sakit Umum Daerah Kuantan Singingi

Analisis pengaruh kepuasan pasien terhadap sanitasi (air bersih, sistem pembuangan air limbah, sistem pembuangan kotoran/jamban, sistem pembuangan sampah, dan sanitasi ruang bangunan) di ruang rawat inap Rumah Sakit Umum Daerah Kuantan Singingi dianalisis menggunakan Korelasi Spearman Rank, Karena merupakan salah satu statistik non parametrik untuk data yang ordinal. Pernyataan yang kualitatif di rubah menjadi kuantitatif menggunakan Skala Likert dengan ketentuan pernyataan : 

a.TS $=$ Tidak Setuju
b.KS = Kurang Setuju
c. $\mathrm{S}=$ Setuju

Hasil data tersebut kemudian diolah menggunakan SPSS. Untuk melihat apak ada pengaruh atau tidak ada pengaruh. Analisa bivariat digunakan untuk melihat hubungan secara statistic antara variabel independen dengan variabel dependen. Analisa bivariat menggunakan uji Chi Square $\left(X^{2}\right)$ dengan menggunakan tingkat kepercayaan $95 \%(\alpha=0.05)$ dengan menggunakan rumus sebagai berikut:

$\mathrm{X}^{2}=\frac{\sum(\mathrm{O}-\mathrm{E})^{2}}{\mathrm{E}}$

Keterangan:

$\mathrm{X}^{2}$ : Chi-Square jumlah baris dalam kolom

$\mathrm{O}:$ Frekuensi yang di observasi (frekuensi empirial)

E : Frekuensi yang diharapkan (frekuensi teoritis)

Dasar pengambilan keputusan yaitu dengan cara probabilistik dimana membandingkan nilai $P$ value dengan $\alpha(0.05)$, sebagai berikut:

a. $\quad$ Jika nilai sig $P$ value $\leq \alpha(0.05)$, maka (Ho) diterima ; (Ha) ditolak .

b. Jika nilai sig $P$ value $\geq \alpha(0.05)$, maka (Ho) ditolak; (Ha) diterima.

Uji signifikansi Spearman menggunakan uji $r$ yang datanya mendekati distribusi normal. Kekuatan hubungan antar variabel ditunjukkan melalui nilai korelasi. Kekuatan korelasi rank spearman dapat dilihat pada Tabel berikut:

Tabel 1. Kekuatan Korelasi Rank Spearman

\begin{tabular}{|c|c|c|}
\hline No & Nilai & Keterangan \\
\hline 1 & $0,000-0,199$ & Sangat lemah \\
\hline 2 & $0,200-0,399$ & Lemah \\
\hline 3 & $0,400-0,599$ & Sedang \\
\hline 4 & $0,600-0,799$ & Kuat \\
\hline 5 & $0,800-1,000$ & Sangat kuat \\
\hline
\end{tabular}

Uji normalitas merupakan uji yang dilakukan sebagai prasyarat untuk melakukan analisis data. Uji normalitas dilakukan sebelum data diolah berdasarkan model-model penelitian yang diajukan. Uji normalitas data bertujuan untuk mendeteksi distribusi data dalam satu variabel yang akan digunakan dalam penelitian. Data yang baik dan layak untuk membuktikan model-model penelitian tersebut adalah data distribusi normal. Uji normalitas yang digunakan adalah uji Kolmogorov-Smirnov. Data dikatakan normal, apabila nilai signifikan lebih besar 0.05 pada $(\mathrm{P}>0.05)$. Sebaliknya, apabila nilai signifikan lebih kecil dari 0.05 pada $(\mathrm{P}<0.05)$ maka data dikatakan tidak normal.

3. Menganalisis dampak kepuasan pasien di ruang rawat inap Rumah Sakit Umum Daerah Kabupaten Kuantan Singingi

Menurut gambaran kesehatan lingkungan rumah sakit untuk mengetahui tingkat kepuasan pasien dapat diklasifikasikan dalam beberapa tingkatan yang dapat dilihat pada Tabel berikut: 
Tabel 2. Karakteristik Responden Berdasarkan Variabel

\begin{tabular}{|c|c|c|}
\hline No & Variabel & Nilai \\
\hline \multirow[t]{4}{*}{1} & Air Bersih & \\
\hline & 1.Puas & $37-67$ \\
\hline & 2.Kurang Puas & $10-32$ \\
\hline & 3.Tidak Puas & $1-9$ \\
\hline \multirow[t]{2}{*}{2} & Kondisi Sistem Pembuangan Kotoran & \\
\hline & $\begin{array}{l}\text { 1.Puas } \\
\text { 2.Kurang Puas }\end{array}$ & $\begin{array}{l}29-62 \\
14-28\end{array}$ \\
\hline \multirow[t]{3}{*}{3} & $\begin{array}{l}\text { 3.Tidak Puas } \\
\text { Kondisi Tempat Sampah }\end{array}$ & $5-13$ \\
\hline & $\begin{array}{l}\text { 1.Puas } \\
\text { 2.Kurang Puas }\end{array}$ & $\begin{array}{l}43-56 \\
12-25\end{array}$ \\
\hline & $\begin{array}{l}\text { 3.Tidak Puas } \\
\text { Kondisi Saluran Pembuangan Limbah }\end{array}$ & $2-11$ \\
\hline 4 & $\begin{array}{l}\text { 1.Puas } \\
\text { 2.Kurang Puas } \\
\text { 3.Tidak Puas }\end{array}$ & $\begin{array}{r}38-46 \\
13-32 \\
1-11\end{array}$ \\
\hline \multirow[t]{2}{*}{5} & Sanitasi Ruang Bangunan & \\
\hline & $\begin{array}{l}\text { 1.Puas } \\
\text { 2.Kurang Puas } \\
\text { 3.Tidak Puas }\end{array}$ & $\begin{array}{c}36-59 \\
10-30 \\
1-9\end{array}$ \\
\hline
\end{tabular}

Dari Tabel klasifikasi diatas dapat disimpulkan bahwa setiap variable mempunyai frekuensi kepuasan yang berbeda-beda. Variabel terdiri dari air bersih, kondisi sistem pembuangan, kondisi tempat sampah, kondisi saluran pembuangan limbah dan sanitasi ruang bangunan.

\section{HASIL DAN PEMBAHASAN}

Dari hasil observasi kepada kepala IKLRS (Instalasi Kesehatan Lingkungan Rumah Sakit) Kuantan Singingi yang telah dilakukan didapatkan gambaran tentang masing-masing keadaan sanitasi diruang rawat inap kelas satu, dua dan tiga RSUD Kabupaten Kuantan Singingi dapat dilihat pada Tabel :

Tabel 3.Gambaran Sanitasi Ruang Rawat Inap RSUD Kuantan Singingi

\begin{tabular}{|c|c|c|c|c|c|c|c|}
\hline \multirow[b]{2}{*}{ No } & \multirow[b]{2}{*}{ Nama Ruangan } & \multirow[b]{2}{*}{ Kelas } & \multicolumn{5}{|c|}{ Kategori } \\
\hline & & & $\begin{array}{c}\text { Sumber Air } \\
\text { Bersih }\end{array}$ & $\begin{array}{c}\text { Sistem } \\
\text { Pembuangan } \\
\text { Kotoran }\end{array}$ & $\begin{array}{l}\text { Kondisi } \\
\text { Tempat } \\
\text { Sampah }\end{array}$ & $\begin{array}{c}\text { Saluran } \\
\text { Pembuangan Air } \\
\text { Limbah }\end{array}$ & $\begin{array}{c}\text { Sanitasi Ruang } \\
\text { Bangunan }\end{array}$ \\
\hline \multirow{3}{*}{1} & \multirow{3}{*}{ Ruang A } & I & Baik & Baik & Baik & Baik & Baik \\
\hline & & II & Baik & Baik & Baik & Baik & Baik \\
\hline & & III & Baik & Sedang & Baik & Sedang & Baik \\
\hline \multirow{3}{*}{2} & \multirow{3}{*}{ Ruang B } & I & Baik & Baik & Baik & Baik & Baik \\
\hline & & II & Baik & Baik & Baik & Baik & Baik \\
\hline & & III & Baik & Sedang & Baik & Sedang & Baik \\
\hline \multirow{3}{*}{3} & \multirow{3}{*}{ Ruang C } & I & Baik & Baik & Baik & Baik & Baik \\
\hline & & II & Baik & Baik & Baik & Baik & Baik \\
\hline & & III & Baik & Sedang & Baik & Sedang & Baik \\
\hline
\end{tabular}

Dari hasil observasi kepada kepala IKLRS Kuantan Singingi yang telah dilakukan didapatkan gambaran tentang masing-masing keadaan sanitasi diruang rawat inap kelas satu, dua dan tiga RSUD Kabupaten Kuantan Singingi adalah : 


\section{Sumber Air Bersih}

Dari hasil observasi untuk keadaan fasilitas sanitasi (sumber air bersih) kelas satu, dua dan tiga RSUD Kuantan Singingi termasuk kedalam kategori keadaan sanitasi baik. Dalam penilaian keadaan fasilitas sanitasi untuk sumber air ada tiga komponen yang dilihat yaitu kuantitas, kualitas dan sarana.

Dari segi kuantitas untuk penyediaan air bersih yang ada di ruang rawat inap telah memenuhi persyaratan, dimana untuk kebutuhan air diruang rawat inap kelas I, II dan III adalah 50.500 liter/hari. Dari segi kualitas untuk sumber air bersih yang berada diruang rawat inap kelas I,II dan III sudah memenuhi persyaratan yaitu tidak berasa, tidak berwarna dan tidak berbau. Sedangkan dari segi sarana sumber air bersih sudah memenuhi persyaratan menurut Keputusan Menteri Kesehatan RI nomor 1204/MENKES/SK/X/2004, keadaan fasilitas sanitasi (sumber air bersih) di RSUD Kuantan Singingi sudah memenuhi persyaratan yaitu : berasal dari sumur bor dan PDAM. Sarana penampungan air bersih tertutup dan pendistribusian tidak bocor.

\section{Sistem Pembuangan Kotoran}

Dari hasil observasi untuk keadaan fasilitas sanitasi (sistem pembuangan kotoran) diruang rawat inap pada kelas I dan II termasuk kedalam kategori baik, sedangkan untuk kelas III termasuk dalam kategori sedang. Dalam penilaian keadaan fasilitas sanitasi untuk sistem pembuangan kotoran ada 2 komponen yang dilihat yaitu kuantitas dan lantai.

Dari segi kuantitas fasilitas sanitasi sudah memenuhi persyaratan menurut KEPMENKES RI nomor 1204/MENKES/SK/X/2004, yaitu : tersedia toilet khusus untuk unit rawat inap. Untuk kelas I dan II, toilet berada di dalam ruang rawat inap itu sendiri sedangkan untuk rawat inap kelas III berada diluar ruangan. Jumlah toilet dan kamar mandi yang ada di ruang rawat inap RSUD Kuantan Singingi sudah memenuhi persyaratan menurut Keputusan Menteri Kesehatan RI nomor 1204/MENKES/SK/X/2004 yaitu untuk setiap 10 tempat tidur sudah terdapat 1 toilet dan 1 kamar mandi. Dari hasil observasi yang telah dilakukan untuk lantai toilet sudah memenuhi persyaratan yaitu untuk lantai kamar toilet terbuat dari bahan yang kuat, kedap air, tidak licin, berwarna terang, mudah dibersihkan dan tidak adanya genangan air yang dapat menjadi perindukan vektor pembawa penyakit khususnya nyamuk.

Dari hasil observasi untuk keadaan fasilitas sanitasi (kondisi tempat sampah) kelas satu, dua dan tiga RSUD Kuantan Singingi termasuk kedalam kategori keadaan sanitasi baik. Menurut Keputusan Menteri Kesehatan RI nomor 1204/MENKES/SK/X/2004, keadaan fasilitas sanitasi (pembuangan sampah) di RSUD Kuantan Singingi sudah memenuhi persyaratan yaitu : untuk tempat sampah terbuat dari bahan yang kuat, kedap air, memiliki tutup dan mempunyai permukaan yang halus pada bagian dalamnya sehingga mudah dibersihkan.

\section{Kondisi Saluran Pembuangan Air Limbah}

Dari hasil observasi untuk keadaan fasilitas sanitasi (kondisi saluran pembuangan air limbah) kelas I dan II RSUD Kuantan Singingi termasuk kedalam kategori keadaan sanitasi baik sedangkan untuk kelas III termasuk kedalam kategori sedang. Hasil yang membedakan dari keadaan fasilitas sanitasi adalah ada beberapa ruangan yang tidak memiliki washtafel. Menurut Keputusan Menteri Kesehatan RI nomor 1204/MENKES/SK/X/2004, keadaan fasilitas sanitasi (sarana pembuangan air limbah) di RSUD Kuantan Singingi sudah memenuhi persyaratan yaitu : dilakukannya pengelolaan melalui instalasi pengelolaan limbah dan disalurkan melalui saluran tertutup, kedap air, dan lancar. Semua air limbah yang berasal dari seluruh ruangan yang ada di RSUD Kuantan Singingi akan dialirkan ke septick tank sebelum disalurkan ke induk IPAL.

\section{Sanitasi Ruang Bangunan}

Dari hasil observasi untuk keadaan fasilitas sanitasi (sanitasi ruang bangunan) kelas I, II dan III RSUD Kuantan Singingi termasuk kedalam kategori keadaan sanitasi baik. Lantai terbuat dari bahan yang kuat, permukaan rata, berwarna terang, mudah dibersihkan, kedap air dan tidak licin. Pembersihan lantai menggunakan sapu kemudian dibersihkan dengan menggunakan larutan desinfektan untuk mencegah penyakit. Keadaan dinding kedap air, permukaan rata baik diluar maupun didalam ruangan, mudah dibersihkan, berwarna terang dan sudah menggunakan cat yang tidak luntur. Dalam hal ini RSUD Kuantan Singingi telah memenuhi persyaratan konstruksi. 


\section{Gambaran Tingkat Kepuasan Pasien Rawat Inap}

Berdasarkan hasil penelitian diperoleh gambaran sanitasi ruang rawat inap berdasarkan variabel dapat disajikan pada Tabel dibawah ini:

Tabel 4. Gambaran Kepuasan Pasien Ruang Rawat Inap

\begin{tabular}{ccc}
\hline Tingkat Kepuasan & Frekuensi & Persentase (\%) \\
\hline Tidak Puas & $<32$ & 0 \\
Kurang Puas & $32-64$ & 0 \\
Puas & $65-96$ & $100 \%$ \\
\hline
\end{tabular}

Berdasarkan Tabel hasil penelitian dari responden pasien rawat inap RSUD Kuantan Singingi atas kuesioner yang diberikan dari total dimensi sumber air bersih, kondisi sistem pembuangan kotoran, kondisi tempat sampah, kondisi saluran pembuangan limbah dan sanitasi ruang bangunan adalah $0 \%$ menyatakan tidak puas, $0 \%$ menyatakan kurang puas dan $100 \%$ menyatakan puas. Dari hasil tersebut menunjukkan bahwa sanitasi ruang bangunan yang terdapat di RSUD Kuantan Singingi tergolong bersih dan nyaman bagi para pasien dan pengunjung.

\section{Dampak Kepuasan Pasien Rawat Inap RSUD Kuantan Singingi}

Kenyamanan merupakan faktor penting untuk menarik pasien yang dapat menjamin kelangsungan berobat dan kenyamanan suatu bentuk jasa yang tidak bisa dilihat dan diraba. Kenyamanan juga penting karena dapat mempengaruhi kepercayaan pasien dalam pelayanan kesehatan. Kenyamanan berkaitan erat dengan lingkungan yang asri, kebersian ruangan, kebersihan WC, kelengkapan ruangan, peralatan medis dan kebersian makanan dan minuman.

Dari penelitian sentuhan psikologis yang bisa disampaikan perawat, dan tim medis lainnya kepada pasien akan mengurangi stress yang dialaminya pada masa sakit, dan ternyata kelelahan psikis berkontribusi terhadap penyakit yang diderita pasien semakin parah. Motivasi dari tim medis bisa menurunkan kecemasan dengan memberikan dukungan-dukungan emosional berupa kesabaran, perhatian, motivasi supaya pasien akan sembuh lebih cepat. Dampak kepuasan dari pasien ini dapat meningkatkan citra dan mutu RSUD Kuantan Singingi menjadi baik di kalangan masyarakat dan pemerintah di Kabupaten Kuantan Singingi.

\section{Uji Reliabilitas}

Pengujian reliabilitas pada penelitian ini menggunakan Alpha Cronbach dengan menggunakan bantuan program SPSS 25. Hasil perhitungan program tersebut dapat dilihat pada tabel :

Tabel 5. Hasil Uji Reliabilitas Sanitasi Ruang Rawat Inap dan Kepuasan Pasien

\begin{tabular}{lcc}
\hline No & Variabel & Koefisien Reliabilitas (Alpha) \\
\hline $\mathbf{1}$ & Sumber Air Bersih (X1) & 0,858 \\
$\mathbf{2}$ & Sistem Pembuangan Kotoran (X2) & 0,756 \\
$\mathbf{3}$ & Kondisi Tempah Sampah (X3) & 0,73 \\
$\mathbf{4}$ & Saluran Pembuangan Air Limbah (X4) & 0,853 \\
$\mathbf{5}$ & Sanitasi Ruang Bangunan (X5) & 0,84 \\
$\mathbf{6}$ & Kepuasan Pasien (Y) & 0,885
\end{tabular}

Berdasarkan tabel Dapat disimbulkan bahwa hasil koefisien reliabilitas (alpha) yang diperoleh lebih besar dari 0,60 maka dapat dikatakan bahwa instrumen yang digunakan andal, artinya suatu instrumen yang dapat dipercaya untuk digunakan sebagai alai pengumpul data atau mengukur obyek yang telah ditetapkan, sebagaimana Arikunto (2006) bahwa reliabilitas menunjukkan pada suatu pengertian bahwa suatu instrumen cukup dapat dipercaya untuk digunakan sebagai alat pengumpul data karena instrumen tersebut cukup baik. 


\section{Uji Validitas}

Setelah dilakukan perhitungan dengan teknik korelasi "product moment" diperoleh koefisien korelasi butir (r-hitung) untuk variabel bebas adalah sumber air bersih (X1), kondisi sistem pembuangan kotoran (X2), kondisi tempat sampah (X3), kondisi saluran pembuangan air limbah (X4), dan sanitasi ruangan bangunan (X5) dan variabel terikat adalah kepuasan pasien (Y) dengan $\mathrm{n}=70$ orang, dengan alpha 0,05 di dapat $\mathrm{r}$ tabel 0,235 , artinya bila $\mathrm{r}$-hitung $>\mathrm{r}$-tabel, maka butir pertanyaan tersebut dapat digunakan (valid). Dari perhitungan statistik untuk masing-masing variabel, ternyata bahwa $\mathrm{r}$ hitung yang diperoleh lebih besar dari r-tabel, sehingga dikatakan bahwa semua butir kuesioner berpredikat valid. Nilai-nilai koefisien korelasi untuk uji validitas instrumen setiap variabel, disajikan pada lampiran 7.

\section{Hasil Analisis Bivariat Chi-Square}

Analisis bivariat bertujuan untuk mengetahui hubungan antara variabel independent dengan variabel dependent dengan menggunakan uji chi square. Adanya hubungan antara sanitasi ruang rawat inap dengan tingkat kepuasan pasien di RSUD Kuantan Singingi ditunjukkan dengan nilai $p<0,05$. Analisa bivariat dalam penelitian ini ditampilkan dalam bentuk Tabel :

Tabel 6. Hasil Uji Chi-Square Sanitasi Ruang Rawat Inap terhadap Kepuasan Pasien

\begin{tabular}{ccccc}
\hline Variabel & P value & df & $\alpha=5 \%$ & Keterangan \\
\hline Sumber Air Bersih (X1) & 16.556 & 8 & 15.507 & Signifikan \\
Sistem Pembuangan Kotoran (X2) & 16.170 & 8 & 15.507 & Signifikan \\
Kondisi Tempat Sampah (X3) & 16.640 & 6 & 12.592 & Signifikan \\
Saluran Pembuangan Air Limbah (X4) & 12.685 & 6 & 12.592 & Signifikan \\
Sanitasi Ruangan Bangunan (X5) & 17.637 & 8 & 15.507 & Signifikan \\
\hline
\end{tabular}

Hasil uji statistik dengan uji Chi Square menunjukkan bahwa semua variabel bebas mempunyai nilai $\mathrm{P}$ value $>\alpha=5 \%$ maka dapat disimpulkan bahwa hipotesis diterima yaitu ada hubungan yang signifikan antara sanitasi ruang rawat inap dengan tingkat kepuasan pasien di RSUD Kuantan Singingi. pada variabel sumber air bersih (X1) diperoleh nilai $\mathrm{P}$ value $=16.556$ yang menunjukkan bahwa lebih besar dari nilai tabel $\alpha(0.05)=15.507$ yang berarti bahwa ada hubungan antara sumber air yang berasal dari PAM/sumur dengan kepuasan pasien rawat inap di RSUD Kuantan Singingi. Hasil observasi oleh peneliti pada air sumur yang tidak berwarna, tidak mempunyai rasa dan jernih di ruang rawat inap sehingga tidak menimbulkan bau yang tidak sedap karena sering dibersihkan dan bagusnya perhatian pihak rumah sakit akan kebersihan sumber air.

Pada variabel sistem pembuangan kotoran $(\mathrm{X} 2)$ diperoleh nilai $\mathrm{P}$ value $=16.170$ yang menunjukkan bahwa lebih besar dari nilai tabel $\alpha(0.05)=15.507$ yang bearti bahwa ada hubungan antara sistem pembuangan kotoran dengan kepuasan pasien rawat inap di RSUD Kuantan Singingi. Hasil observasi oleh peneliti pada kondisi sistem pembuangan kotoran yang jauh, tidak terjangkau oleh kecoa atau tikus, jamban mudah digunakan dan mudah dibersihkan di ruang rawat inap sehingga tidak menimbulkan bau yang tidak sedap membuat pasien merasa nyaman dan puas

Pada variabel kondisi tempat sampah $(\mathrm{X} 3)$ diperoleh nilai $\mathrm{P}$ value $=16.640$ yang menunjukkan bahwa lebih besar dari nilai tabel $\alpha(0.05)=12.592$ maka dapat disimpulkan bahwa hipotesis diterima yaitu ada hubungan antara kondisi tempat sampah dengan kepuasan pasien rawat inap di RSUD Kuantan Singingi. Hasil observasi oleh peneliti pada kondisi tempat sampah yang mempunyai tutup mudah dibuka tanpa mengotori tangan, tempat sampah sudah dibersihkan dan tidak terjangkau oleh lalat atau tikus di ruang rawat inap sehingga tidak menimbulkan bau yang tidak sedap membuat pasien merasa nyaman dan puas.

Pada variabel kondisi saluran pembuangan air limbah (X4) diperoleh nilai $\mathrm{P}$ value $=12.685$ yang menunjukkan bahwa lebih besar dari nilai tabel $\alpha(0.05)=12.592$ maka dapat disimpulkan bahwa hipotesis diterima yaitu ada hubungan antara kondisi saluran pembuangan air limbah dengan kepuasan pasien rawat inap di RSUD Kuantan Singingi. Hasil observasi oleh peneliti pada kondisi saluran pembuangan air limbah yang mengalir dengan lancar sehingga air limbah tidak menimbulkan bau yang tidak sedap dan membuat pasien merasa nyaman dan puas.

Pada variabel sanitasi ruang bangunan (X5) diperoleh nilai $\mathrm{P}$ value $=17.637$ yang menunjukkan bahwa lebih besar dari nilai tabel $\alpha(0.05)=15.507$ maka dapat disimpulkan bahwa hipotesis diterima 
yaitu ada hubungan antara sanitasi ruang bangunan dengan kepuasan pasien rawat inap di RSUD Kuantan Singingi. Hasil observasi oleh peneliti pada kondisi sanitasi ruang bangunan yang mempunyai lantai kedap air, tidak licin, tidak retak dan mudah dibersihkan, dinding dan langit-langit berwarna terang dan bersih di ruang rawat inap sehingga ruangan pasien terang dan mendapatkan cahaya dengan intensitas cahaya yang cukup akan membuat pasien merasa nyaman dan puas.

\section{Uji Normalitas}

Pengujian normalitas data, dilakukan dengan dua cara yaitu dibuat histogram untuk distribusi standardized residual, dan dibuat kurva normal pada setiap model. Untuk memperoleh hasil yang akurat, perhitungan dilakukan dengan program SPSS versi 25.

\section{Persamaan Regresi}

Analis regresi digunakan untuk mengukur besarnya pengaruh variabel bebas dalam hal ini dimensi sumber air bersih (X1), kondisi sistem pembuangan kotoran (X2), kondisi tempat sampah (X3), kondisi saluran pembuangan air limbah (X4), dan sanitasi ruang bangunan (X5) terhadap variabel terikat yaitu kepuasan pasien $(\mathrm{Y})$. Hasil perhitungan dengan menggunakan SPSS 25 adalah bisa dilihat pada Tabel berikut :

Tabel 10. Persamaan Regresi Sanitasi Ruang Rawat Inap terhadap Kepuasan Pasien

\begin{tabular}{|c|c|c|c|c|c|}
\hline \multicolumn{6}{|c|}{ Coefficients $^{\mathrm{a}}$} \\
\hline \multirow{2}{*}{ Model } & \multicolumn{2}{|c|}{$\begin{array}{c}\text { Unstandardized } \\
\text { Coefficients }\end{array}$} & \multirow{2}{*}{$\begin{array}{r}\text { Standardized } \\
\text { Coefficients }\end{array}$} & \multirow[t]{2}{*}{$\mathrm{t}$} & \multirow[t]{2}{*}{ Sig. } \\
\hline & B & Std. Error & & & \\
\hline (Constant) & 5.826 & 3.951 & & 3.475 & 0.005 \\
\hline Sumber Air Bersih & 0.126 & 0.078 & 0.193 & 2.624 & 0.009 \\
\hline Sistem pembuangan Kotoran & 0.015 & 0.077 & 0.023 & 2.191 & 0.004 \\
\hline Kondisi Tempat sampah & 0.185 & 0.084 & 0.122 & 2.002 & 0.020 \\
\hline Saluran Pembuangan Air Limbah & 0.122 & 0.096 & 0.028 & 2.229 & 0.019 \\
\hline Sanitasi Ruang Bangunan & 0.188 & 0.064 & 0.165 & 3.359 & 0.013 \\
\hline
\end{tabular}

a. Dependent Variable: Kepuasan Pasien berikut :

Dari tabel koefisien tersebut diatas, maka nilai persamaan regresi berganda dapat dituliskan sebagai

$\mathrm{Y}=\mathrm{a}+\mathrm{b} 1 \mathrm{X}_{1}+\mathrm{b} 2 \mathrm{X}_{2}+\mathrm{b} 3 \mathrm{X}_{3}+\mathrm{b} 4 \mathrm{X}_{4}+\mathrm{b} 5 \mathrm{X}_{5}$

$\mathrm{Y}=5.826+0.126 \mathrm{X}_{1}+0.015 \mathrm{X}_{2}+0.185 \mathrm{X}_{3}+0.122 \mathrm{X}_{4}+0.188 \mathrm{X}_{5}$

\section{KESIMPULAN}

Berdasarkan hasil penelitian serta pembahasan mengenai pengaruh sanitasi ruang rawat inap (sumber air bersih, kondisi sistem pembuangan kotoran, kondisi tempat sampah, kondisi saluran pembuangan air limbah dan sanitasi ruang bangunan) terhadap kepuasan pasien RSUD Kabupaten Kuantan Singingi, dapat disimpulkan sebagai berikut:

1. Hasil penelitian menunjukkan bahwa sanitasi (sumber air bersih, kondisi sistem pembuangan kotoran, kondisi tempat sampah, kondisi saluran pembuangan air limbah dan sanitasi ruang bangunan) berpengaruh secara signifikan terhadap kepuasan pasien. Persentase tertinggi yang menyatakan puas adalah sebesar $71 \%$ pada variable kondisi tempat sampah, kurang puas sebesar $29.42 \%$ pada variabel sumber air bersih dan tidak puas sebesar $5.98 \%$ pada variabel kondisi tempat sampah. Jadi dapat disimpulkan bahwa pasien merasa puas dengan kualitas dan pelayanan rumah sakit.

2. Berdasarkan hasil pengujian analisa hipotesis yaitu uji chi square menunjukkan bahwa variabel sanitasi ruang rawat inap berhubungan dan signifikan terhadap kepuasan pasian rawat inap, maka dapat disimpulkan bahwa hipotesis diterima yaitu ada pengaruh antara sanitasi ruang bangunan dengan kepuasan pasien rawat inap.

erdasarkan hasil penelitian dari wawancara pasien merasa puas dan nyaman dengan pelayanan yang telah diberikan. Kepuasan dari pasien ini dapat meningkatkan citra dan mutu rumah sakit menjadi baik di kalangan masyarakat dan pemerintah di Kabupaten Kuantan Singingi. 


\section{UCAPAN TERIMAKASIH}

Penulis menyampaikan terimakasih kepada seluruh pihak yang membantu dalam kelancaran penelitian ini.

\section{DAFTAR PUSTAKA}

Adisasmito, W. 2007. Sistem Manajemen Lingkungan Rumah Sakit. PT. Raja Grafindo Persada, Jakarta.

Arikunto, S. 2006. Metodologi Penelitian Suatu Pendekatan Praktek. Jakarta: PT. Rineka Cipta.

Departemen Kesehatan RI. 2004. Keputusan Menteri Kesehatan Republik Indonesia Nomor 1204/Menkes/SK/X/2004, tentang Persyaratan Kesehatan Lingkungan Rumah Sakit. Jakarta.

Febri, B., Furwanti, A dan Hendriani, S. 2018. Dimensi Pelayanan Dalam Membentuk Kepuasan dan Citra Positif Pasien Pada Puskesmas di Kabupaten Kuantan Singingi. Jurnal Tepak Manajemen Bisnis. $\mathrm{X}(2): 220-225$.

Kotler, P. 2000. Manajemen Pemasaran Edisi Milenium Jilid I Edisi Kesepuluh. Erlangga : Jakarta.

Nawangsari, E. R. 2011. Model Pelayanan Berbasis Pelanggan (Studi Evaluasi di Bagian Unit Rawat Inap Rumah Sakit Umum Daerah Sidoarjo Jawa Timur). Jurnal Kedokteran Kesehatan 3 (2) : 21-30.

Nurlinda, A. 2013. Gizi dalam Siklus Daur Kehidupan. Andi Offset. Yogyakarta.

Prakash, B. 2010. Patient Satisfaction. www.ncbi.nlm.nih.gov. Diakses pada tanggal 27 Juli 2019.

Sabarguna, B.S dan Rubaya, A.K. 2011. Sanitasi Lingkungan \& Bangunan Pendukung Kepuasan Pasien Rumah Sakit. Salemba Medika. Jakarta.

Tjiptono, F. 2005. Service, Quality dan Satisfication.Yogyakarta.

Undang-Undang RI Nomor 44 Tahun 2009 tentang Rumah Sakit. Jakarta.

Utami, R.A. 2018. Dampak Sanitasi Lingkungan terhadap Kesehatan Masyarakat di Wilayah Pesisir Kecamatan Kota Agung Kabupaten Tanggamus Provinsi Lampung. Fakultas Keguruan dan Ilmu Pendidikan Universitas Lampung Bandar Lampung.

Wati, H.S. 2012.Hubungan Mutu Pelayanan dengan Kepuasan Pasien Rawat Inap di Rumah Sakit Umum Daya Makassar. Makassar: Universitas Hasanuddin. 